\title{
In reply to the letter to the editor: "In reply to Fiorino et al: The central role of the radiation oncologist in the multidisciplinary and multi-professional model of modern radiation therapy"
}

Citation for published version (APA):

Fiorino, C., Jeraj, R., Clark, C. H., Garibaldi, C., Georg, D., Muren, L., van Elmpt, W., Bortfeld, T., \& Jornet, N. (2021). In reply to the letter to the editor: "In reply to Fiorino et al: The central role of the radiation oncologist in the multidisciplinary and multi-professional model of modern radiation therapy". Radiotherapy and Oncology, 155, E22-E23. https://doi.org/10.1016/j.radonc.2020.12.033

Document status and date:

Published: 01/02/2021

DOI:

10.1016/j.radonc.2020.12.033

Document Version:

Publisher's PDF, also known as Version of record

Document license:

Taverne

Please check the document version of this publication:

- A submitted manuscript is the version of the article upon submission and before peer-review. There can be important differences between the submitted version and the official published version of record. People interested in the research are advised to contact the author for the final version of the publication, or visit the DOI to the publisher's website.

- The final author version and the galley proof are versions of the publication after peer review.

- The final published version features the final layout of the paper including the volume, issue and page numbers.

Link to publication

\footnotetext{
General rights rights.

- You may freely distribute the URL identifying the publication in the public portal. please follow below link for the End User Agreement:

www.umlib.nl/taverne-license

Take down policy

If you believe that this document breaches copyright please contact us at:

repository@maastrichtuniversity.nl

providing details and we will investigate your claim.
}

Copyright and moral rights for the publications made accessible in the public portal are retained by the authors and/or other copyright owners and it is a condition of accessing publications that users recognise and abide by the legal requirements associated with these

- Users may download and print one copy of any publication from the public portal for the purpose of private study or research.

- You may not further distribute the material or use it for any profit-making activity or commercial gain

If the publication is distributed under the terms of Article 25fa of the Dutch Copyright Act, indicated by the "Taverne" license above,

Download date: 26 Apr. 2023 


\begin{abstract}
In reply to the letter to the editor: "In reply to Fiorino et al: The central role of the radiation oncologist in the multidisciplinary and multiprofessional model of modern radiation therapy"
\end{abstract}

\section{To the Editor}

We thank Alongi and colleagues for their letter [1] that gives us the opportunity to better highlight and expand the spirit and the content of our paper on "grand challenges for medical physics" [2].

As explained in our paper, the conclusions resulted from a thorough and inclusive preparatory path driven by the ESTRO FUTURE physics group [3,4], involving the ESTRO physics community (that participated in an initial on-line survey) and many experts outside this community, including radiation oncologists as well as others. One of the cornerstones of this process was the involvement of "out-of-the-field" experts, taking the opportunity to feed into our field with different and challenging points of view on the four major items identified through the preparation phase.

This process culminated with a one-day workshop bringing together 36 experts, including several leading radiation oncologists, but also imaging and computer scientists, biologists and others who openly debated these issues. The title of the meeting was: "the most provocative questions to medical physics in radiation oncology". We therefore aimed to be provocative in order to stimulate a lively discussion that was ultimately the inspiring basis of our paper. Clearly, the task to move forward in identifying new horizons for medical physics addressing new challenges (condensed in the four selected issues) was the one which is reflected in the visions and directions depicted in this paper.

Even due to this very inclusive yet directed process, we do not fully understand the surprise raised by the authors regarding a possible omission of the role of radiation oncologists. Radiation oncologists were included in the process, however, as the title of our paper clearly states, the goal was to identify and discuss "grand challenges" for medical physics in radiation oncology, not radiation oncology in general. We would be very pleased to see similar initiatives from other branches of the multi-disciplinary field of radiation oncology, leading to mutually enriching perspectives.

Furthermore, we would like to emphasize that the key items, summarized in Table I of our paper, as well as the final (visionary) remarks [2] focused exclusively on what medical physics is expected to do and not what others should not do.

DOI of original article: https://doi.org/10.1016/j.

To summarize our main conclusions and putting them in clearer perspective, we foresee that the scientific and professional challenges of our times are pushing medical physics to "accelerate toward multi-disciplinarity" [3-7]. Connected to this, medical physicists are also expected to encounter and collaborate with other specialists that are currently not part of the main radiation oncology team. As also underlined by the authors of the letter, the radiation physics core will remain central to our profession (but not exclusive!), retaining "strong and pivotal roles in quality, safety and in managing ever more complex technologies" $[5,8]$. Clearly new challenges will require medical physicists "to continuously update skills and innovate education" [9], adapt curricula to include new fields, reinforce a multi-disciplinary attitude and the spirit of innovation. "Visionary and open leadership, which is able to merge established roles with the exciting new fields" is clearly required to effectively and successfully respond to current and future challenges.

The responsibility of radiation oncologists for leading the clinical process of treating patients needs no discussion, especially in the context of looking to new horizons and challenges for medical physics, both scientifically and professionally.

Finally, perfectly in line with the multi-disciplinary nature of radiation oncology and with the attitude and spirit of ESTRO, our paper underlined the need to work in synergy, in the same room and not in different separate rooms.

As we mentioned in our paper: "medical physicists should develop a mutually synergistic partnership with the other professionals in radiation oncology in leading our field together."

The true driver of radiation oncology comes from the synergy created by the collaboration of all disciplines in the field (radiation oncologists, radiobiologists, RTTs and medical physicists) enabling us together to improve treatment of our patients.

New challenges, once more, reinforce the need to recognize that the best results come from a continuously updated team effort, overcoming outdated schemes: we should all be pulling in the same direction.

The only way that we will be able to face these new challenges effectively and impactfully is to do it together, in the same overarching ESTRO vision of creating "optimal health for all, together" [10].

\section{References}

[1] Alongi F, Arcangeli S, Cuccia F et al. In reply to Fiorino et al.: The central role of the radiation oncologist in the multisciplinary and multiprofessional model of modern radiation therapy. Radiother Oncol 2020 (in press).

[2] Fiorino C, Jeraj R, Clark CH, Garibaldi C, Georg D, Muren L, et al. Grand challenges for medical physics in radiation oncology. Radiother Oncol 2020 (in press).

[3] Bortfeld T, Torresin A, Fiorino C, Andreo P, Gagliardi G, Jeraj R, et al. The research versus clinical service role of medical physics. Radiother Oncol $2015 ; 114: 285-8$. 
[4] Fiorino C, Muren LP, Clark CH, van Elmpt W, Jornet N. Expanding the scientific role of medical physics in radiotherapy: time to act. Radiother Oncol $2015 ; 117: 401-2$.

[5] Fiorino C, Guckenberger M, Schwarz M, Heide UA, Heijmen B. Technologydriven research for radiotherapy innovation. Mol Oncol 2020;14:1500-13.

[6] Baumann M, Krause M, Overgaard J, Debus J, Bentzen SM, Daartz J, et al. Radiation oncology in the era of precision medicine. Nat Rev Cancer 2016;16:234-49.

[7] Burmeister JW, Tracey MW, Kacin SE, Dominello MM, Joiner MC. Improving research in radiation oncology through interdisciplinary collaboration. Radiat Res 2018;190:1-4.

[8] European Commission. N 1681-6803 MJ-AX-14-002-EN-C Energy Protection Radiation $N^{\circ} 174$ European Guidelines on Medical Physics Expert ISSN 16816803, 2014.

[9] Clark CH, Gagliardi G, Heijmen B, Malicki J, Thorwarth D, Verellen D, et al. Adapting training for medical physicists to match future trends in radiation oncology. Phys Imag Radiat Oncol 2019;11:71-5.

[10] Lievens Y, Ricardi U, Poortmans P, Verellen D, Gasparotto C, Verfaillie C, et al. Radiation oncology. Optimal health for all, together. ESTRO vision 2030. Radiother Oncol 2019;136:68-97.
${ }^{a}$ Medical Physics, San Raffaele Scientific Institute, Milano, Italy

${ }^{\mathrm{b}}$ Department of Medical Physics, University of Wisconsin, Madison, USA

${ }^{\mathrm{c}}$ Faculty of Mathematics and Physics, University of Ljubljana, Slovenia

${ }^{\mathrm{d}}$ University College London Hospital, University College London and National Physical Laboratory, UK

${ }^{\mathrm{e}}$ Unit of Radiation Research, IEO European Institute of Oncology, IRCCS,

Milano, Italy

${ }^{\mathrm{f}}$ Division Medical Radiation Physics, Department of Radiation Oncology, Medical University of Vienna/AKH Wien, Vienna, Austria ${ }^{\mathrm{g}}$ Danish Centre for Particle Therapy, Aarhus University Hospital and Aarhus University, Aarhus, Denmark

${ }^{\mathrm{h}}$ Department of Radiation Oncology (MAASTRO), GROW - School for Oncology and Developmental Biology, Maastricht University Medical Centre, Maastricht, The Netherlands

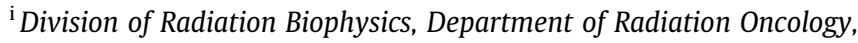
Massachusetts General Hospital and Harvard Medical School, Boston, USA

Claudio Fiorino ${ }^{a}$ Robert Jeraj ${ }^{\mathrm{b}, \mathrm{c}}$ Catharine H. Clark ${ }^{\mathrm{d}}$ Cristina Garibaldi ${ }^{\mathrm{e}}$ Dietmar Georg $^{\mathrm{f}}$ Ludvig Muren $^{\mathrm{g}}$ Wouter van Elmpt ${ }^{\text {h }}$ Thomas Bortfeld ${ }^{\mathrm{i}}$ Nuria Jornet ${ }^{\mathrm{j}}$
${ }^{j}$ Servei de Radiofisica i Radioprotecció. Hospital Sant Pau, Barcelona, Spain

Received 7 December 2020

Received in revised form 21 December 2020 Accepted 21 December 2020

Available online 04 January 2021 